821.163.41-4.09 Дучић, Јован https://doi.org/10.18485/msc.2017.46.2.ch19

Владимир В. ГВОЗДЕН Универзитет у Новом Саду Филозофски факултет
Оригинални научни рад

Примљен: 08. 11. 2016. Прихваћен: 10. 02. 2017.

\title{
ЕСЕЈИСТА ЈОВАН ДУЧИЋ
}

\begin{abstract}
У српској прози нема много књига као што су збирке огледа Благо цара Радована и Jутра са Леутара. Мало је писаца који су се „усудили” да се на овај начин суоче са великим моралистичким темама, јер оне, поред тога што представљају велики изазов, истовремено доносе и знатан ризик за онога ко им приступа. Овај рад, кроз компаративну и контекстуалну анализу, покушава да смести ове есеје унутар шире европске традиције. Показује се да је есејиста Јован Дучић ерудита, еклектичар, индуктивац; по предметима којима се бавио, као и по начину на који им је приступао, он несумњиво припада традицији есејистичког начина писања која свој прави почетак налази код Монтења у 16. веку, а настављаче међу писцима временски много ближим Дучићу, као што су Ралф Валдо Емерсон, аутор књиге Управљање животом; Морис Метерлинк, писац Мудрости и судбине; или Карлајл са својим огледима о херојима. У том смислу, овај хуманистички естета је несумњиво литерарни баштиник „западне цивилизације”, чија је реалност везана за грчко-римску и јудео-хришћанску традицију, као и за модерну традицију државе-нације као темељног амбијента испољавања културе, што такође подразумева и известан немир који се крије иза његовог есејистичкој трагања за „вечним” вредностима и неспорним цивилизацијским постигнућима.

Кључне речи: хеленизам, пасатизам, модернизација, хуманизам, естетизам, индивидуализам, аристократизам, порекло, поезија.
\end{abstract}

Јован Дучић заузима почасно место у канону српске културе, а његово дело је саставни и незаобилазни део наше књижевне класике. Дучић је припадао типу песника и ствараоца који је непрестано углачавао своје дело, стихове, путописе, огледе - а то читаоци изгледа препознају и због тога га посебно цене. Он се посматра као „обожавалац културе” који има „врло развијен историјски смисао” и из прошлости доноси „крти шум драгоцена старог броката" (Савић Ребац 1988: 374), али који то не чини у бекству или повлачењу, већ у делатном додиру са властитом савременошћу, упијајући знања и вештине са самих врела европске културе. Његова поезија је, како пише Аница Савић Ребац, „поезија културе, а ток његова образовања је био такав

\footnotetext{
*vladimir.gvozden@ff.uns.ac rs
} 
да је тек постепено и доста доцкан дошао до најоригиналнијих врела култуpe. И тек онда је цела његова уметничка личност проговорила" (1988: 373). Како је тврдила још Исидора Секулић, у Дучићу је национално оплођено страним довело до једне више културе (1964: 264-265). Времена и захтеви се мењају, али модел одношења према европској култури и њеним траговима који је развио Дучић нажалост није чест ни данас - утолико је, наравно, његов значај већи, што све заједно појачава потребу за једним новим, другачијим читањем и размишљањем о овом драгоценом аутору.

Дучић је био и велики путник (в. Гвозден 2003), и то не само у својству студента или дипломате већ и један особени, интелектуални путник, чије се кретање одвијало међу књигама исто колико и у стварном животу - о томе не само што сведоче непосредни трагови у његовим списима већ и изузетно богата библиотека од преко 5000 књига која се налази у Требињу. Хоризонт тог богатог путовања уливао се и у писање. Књижевни рад Јована Дучића испољавао се у оквирима различитих жанрова - поезије, есеја, књижевне критике, путописа - али је приметно да су проучаваоци своју пажњу углавном усмеравали на поезију. Разлог за то лежао је у рано израженој идеји да његови стихови надмашују све друго што је написао, као што, рецимо, читамо код Милана Кашанина: „престиж и сјај Дучићевих стихова учинили су да се о њему говори искључиво, или бар највише, као о песнику" (1968: 347). Дучићу су, као што истиче Предраг Палавестра у Историји модерне српске књижевности, „признате највеће заслуге за усавршавање песничког израза новије српске лирике и за развој српског стиха" (1986: 253).

Нема сумње око тога да ми о Дучићу највише знамо као о песнику и сјајном стилисти, а много мање о њему као мислиоцу, ерудити, путописцу и есејисти. Благо изара Радована и Јутра са Леутара сведоче о његовој потоњој делатности. (У овом говору о есејисти Јовану Дучићу узети су обзир само есеји схваћени у изворном монтењевском кључу, као необавезне цитатне расправе о различитим темама; шире схватање које и његове књижевнокритичке студије смешта у есеја овде није узето у обзир.) О овим делима је говорено углавном успутно, и некако су све до деведесетих година прошлог века и код читалаца и код критичара била у сенци стихова, па чак и путописа. Мора се рећи да у српској прози нема много књига као што су збирке огледа Благо цара Радована и Јутра са Леутара. Мало је, како се чини, писаца који су се „усудили” да се на овај начин суоче са великим моралистичким темама, јер оне, поред тога што сасвим сигурно представљају велики изазов, истовремено доносе и знатан ризик за онога ко им приступа. Уосталом, и сам Дучић је великим темама на есејистички начин приступио релативно касно, кад је већ био афирмисан као песник и познат као јавна личност.

Поднаслов Блага цара Радована гласи „Књига о судбини”. Књига је обимна и написана је за неколико година (1926-1930), мада је сасвим јасно да је стварана више деценија и да следи низ Дучићевих интелектуалних и моралних занимања током дужег периода. Изашла је као шести том Сабраних дела и представљала је изненађење за критичаре и читаоце, о чему сведоче и прикази у тадашњој периодици. То и не чуди, јер се Дучић пре објављивања 
Блага изара Радована није афирмисао као писац таквог штива. Док је своје путописе које је унео у Градове и химере најпре објављивао на страницама Зоре, Српског књижевног гласника или Политике, то углавном није био случај са огледима, ако се изузму афоризми објављени 1907. године и три мања есеја, објављена у Политици 1924. и 1929. године под насловом „Мисли о песнику", касније припојена Благу изара Радована. Десет мањих есеја под насловом Јутра са Леутара и поднасловом „Речи о човеку”, појавили су се - ако се изузму огледи „О мирноћи”, „О плесу” и „О пријатељству”, објављени тридесетих година у часописима - први пут 1951. године и углавном представљају или припремне радове за Благо цуара Радована, или радове који продужавају и разрађују мисли из претходно објављеног дела. Уз Благо ияара Радована, Јутра са Леутара су вид Дучићевог идејног завештања, сажетак његових осећања и сазнања, као и библиографија пробране и богате лектире.

Уистину, ове књиге јесу збирке кратких есеја - врло одсечних и веома смелих: прва, Благо изара Радована, говори о срећи, љубави, жени, пријатељству, младости и старости, песнику, херојима и пророцима; а друга, Jуmра са Леутара, о мирноћи, мржњи, плесу, љубомори, сујети, страху, разочарању, родољубљу, карактеру и уљудности. Све то личи на каталог битних културолошких и животних проблема, што свакако објашњава популарност ових есеја у време културне кризе и дезоријентације током деведесетих година прошлог века. По предметима којима се бавио, као и по начину на који им је приступао, Дучић несумњиво припада традицији есејистичког начина писања која свој прави почетак налази код Монтења у 16. веку, а настављаче међу писцима временски много ближим Дучићу, као што су Американац Ралф Валдо Емерсон, аутор књиге Управљање животом (1860); Морис Метерлинк, писац Мудрости и судбине (1898); или Карлајл са својим огледима о херојима (1841). ${ }^{1}$ Почетно слово наслова свих Дучићевих огледа уврштених у ове две књиге - отворено и обавезујуће „О” - преузето је из старе монтењевске традиције скоковитог индуктивног кретања око једне теме, проблема, питања.

Међутим, иза тога „О” у наслову сваког есеја дотиче се, као што бива, безброј других питања. Поводом једне појаве или проблема, писац се необавезно креће ка другим појавама и проблемима, присећа се цитата и мисли који са првобитном темом стоје у лабавој вези, а затим допушта да га те нове идеје повуку ка другим, мање или више блиским и сродним мислима и увидима. Тако се читалац, од тачке до тачке, од једне до друге реченице или пасуса, креће заједно са писцем, бивајући каткад са њим потпуно сагласан, понекад настројен критички, па чак и сасвим супротстављен. Па ипак, како се чини, та слобода је управо оно што се допада читаоцу и што његову

\footnotetext{
${ }^{1} \mathrm{O}$ значајној рецепцији ових дела у време Дучићевог рада на есејима сведоче и преводи: Емерсоново Управљање животом објавио је С. Б. Цвијановић 1923. у преводу Исидоре Секулић; Карлајлову књигу О херојима хероизму и обожавању хероја у историји превео је Божидар Кнежевић и објавила Српска књижевна задруга 1903; коначно, вреди поменути да је Метерлинкова Мудрост и судбина објављена 1918. у Загребу у преводу Александра Грлића.
} 
пажњу везује много више за наредни корак, него за онај који тренутно гази. Дучић је био еклектичар, индуктивац, човек пријемчив за разнолике утиске из свакодневног искуства, као и за различите, понекад и сасвим супротне идеје и ставове, учења и школе, за разна становишта и „погледе на свет”, односно како пише Паулина Лебл-Албала у једном од раних и ретких обухватних есеја посвећеним Благу цара Радована: „Широкогруд и толерантан, он мири идеје које изгледају на први поглед противречне, и уме да уочи међу њима узрочне везе или неке скривене афинитете. Потом, на њему својствен деликатан начин, он их усклађује у један склоп” (1938: 273).

Критичари су имали одређене наклоности у избору најбољих и најзначајнијих есеја, мада до данас остаје незаобилазно поглавље о песнику, у којем се излажу Дучићеви ставови о уметности и песничком стваралаштву. То је нека врста вивисекције и самог Дучићевог уметничког стварања, као и улоге песника уопште. Истовремено, овај оглед добро илуструје пишчево дискурзивно мирење противречности које, мора се рећи, нису лако помирљиве. Наиме, у есеју се мешају три основна схватања песника. Прво, у романтичарском духу, он је „најизразитији и најпотпунији тип једне расе. Он је мерило расног генија, сензибилитета, идеологије" (Дучић 1996: 276). Друго, у једном класицистичком духу, непрестано провејава схватање песника као универзалног људског гласа, „тумача божанства” који изражава општу људску природу и лепоту (Исто: 274). Треће, у кључу модернистичког индивидуализма, „песниково је дело увек као једно усамљено острво, које изгледа да има своје сопствено небо и сопствено сунце, на чијем осветљењу зрачи његова сопствена лепота" (Исто: 307). Ова три схватања песника и улоге поезије и иначе су се мешала у Дучићевом стваралаштву, па чак се и он сам, у различитим периодима рада може посматрати у оквиру једног од поменутих модела. Но, рекло би се да све ове тежње, упркос њиховој различитости, па и неспојивости, обједињује дубока аристократска вера да песник - да би заиста то био - мора да створи велико и јединствено дело које би било израз човековог бића и његове чежње за складом, како у природи, тако и у властитој психологији. У том смислу, Јован Дучић се показује као хуманистички естета за којег је уметност нешто надређено у односу на друге људске делатности, нешто надисторијско што може да обухвати и усклади свако пролазно искуство.

Оглед „О херојима” је посебно занимљив ако се посматра у односу према есеју о песнику: наиме, естетичар и проповедник уметности ради уметности одједном се претвара у човека забринутог за улогу великог човека у свету. Занимљиво је то што за Дучића, под утицајем Карлајла, а карактеристично за преображај идеје у модерни, херојство не значи храброст, односно дело које се остварује у једном тренутку, већ истрајност, неограничену преданост идеји:

Постоји разлика између идеала и фикције, за које људи умиру често са истом лакоћом. Идеал, то је једно сазнање о највишој истини; а фикција, то је само пуста машта. Ка идеалу се иде памећу и науком, а ка фикцији се иде страшћу и перверзијом. Херој умире само за идеал (1996: 331). 
У огледима упознајемо и Дучићев психолошки лик, који је у разним тренуцима постављен на различитим, па чак и супротним позицијама - то познају и читаоци његове поезије. У ствари, рекло би се да је управо главна врлина и мана ових есеја у хетерогености, пошто је она безрезервна, а не случајна и неконтролисана. Извор нашег задовољства у читању Блага ц̧ара $\mathrm{Pa}$ дована и Јутара са Леутара лежи између осталог у томе што смо у стању да трагамо за Дучићевим наклоностима и слабостима, односно да, попут правих литерарних ловаца, пратимо његову лектиру, да се подсећамо идеја потеклих из културних кругова кроз које се песник креће, да упознајемо његов укус и његове реакције на низ стварних животних питања - и да притом кроз такво помало воајерско уживање чак заборавимо да ли су његове идеје нове или изузетне. Велика константа ових есеја је стална спремност њиховог аутора за разговор и размишљање. На који год начин неко мислио о томе, настајање и одржавање личног идентитета, чему су посвећене и ове књиге настале у одсуству херојског пробоја изван свакодневне егзистенције, може се остварити само дијалошки. Дучић уме да говори и он напросто говори о својим мишљењима и о својим искуствима, разговара да би остварио утисак исповести, али и ради личног задовољства. Ако безмало све у овим есејима осцилује и ништа није стабилно, једино је та воља да се саопшти властита мисао, да се храбро изиђе у сусрет великим идејама константна и непроменљива. Важно за популарност ових есеја је и то што у њима Дучић не доцира; као човек који говори отворено и храбро, па чак и ризично, али са одређеношћу и искреношћу, он остварује присан додир са читаоцима. Коначно, захваљујући динарској речитости, помало латинском укусу за лепу или поентирану реч, те широкој лектири у којој преовлађује наклоност за античку мудрост и личне импресије, он успева да буде више занимљив него доследан.

Много пута је истицано да је у Дучићевим огледима важну улогу одиграло његово познавање старе грчке и римске културе, које су за њега највиша еманација медитеранства.

Поред неспорног статуса Дучића као франкофила, он је непоколебљиви хеленофил. Као што је истакао Слободан Витановић у књизи Јован Дучић у знаку Атене, Дучић је „заљубљеник у дубину, ширину, узвишеност, јасност, лепоту и људскост мисли грчких филозофа, уметника и државника, очаран њиховим непоновљивим смислом за меру, хармонију, за равнотежу између општег и посебног...” (Витановић 1997: 13). Песник у целокупном стваралаштву преноси схватање по којем је Грчка место за којим се чезне, о којем се сања, које је већ познато и које је саставни део стереотипа о „повратку кући”, у колевку људске цивилизације и највиших вредности. Песник је више година боравио у Атини и Каиру, и тако непосредно обогатио своје познавање ових култура. Њему су позната учења Сократа, Епиктета, Марка Аурелија, Цицерона и Сенеке, исто тако као и схватања „модерних” Монтења, Русоа, Волтера, Лока, Карлајла, Емерсона или Мигела де Унамуна. Тако, на пример, већ први оглед из Jутара са Леутара, започиње низом ставова старих Грка о апатији и атараксији: „Уопште, мирноћа за старински грчки свет била је врхунац не само филозофске себичности него и врхунац уметничке лепоте: 
мирноћа у лепоти и лепота у мирноћи" (1969: 37). Мора се признати, заједно са историчарем Луисом Мамфордом, да се у оваквој слици, развијаној најпре у ренесанси, подстицаној у 18. столећу и коначно уобличеној у романтизму, лако заборављају сви они дивљи ирационални и узбуркани видови грчког живота „које налазимо код трагичара и драматичара или у грубим рустичним шалама или бестидностима које налазимо у Аристофановим комедијама" (Мамфорд 2001: 167). У складу са овим дискурсом, савремена Грчка није била предмет поређења са чарима замишљене Грчке.

Наравно, овакав Дучићев хеленизам нема само идеолошку, већ и естетску функцију. Славко Леовац је истицао да је Дучићева „идеја о грчки лепом бит његове поетике. То је она хармонија која очовечује, уравнотежава и осмишљава, хармонија настала из хеленског свестраног живота и мишљења" (Леовац 1985: 94). Но, у кључу већ поменутог кретања у разним правцима („многостраности”), тај исти оглед неће остати само при погледима старих Грка, већ ће се из тог језгра ширити према схватањима римских стоика, попут Марка Аурелија или Цицерона, све до појединих навода или реминсценција на дела или схватања Монтескјеа, Гетеа и Шилера. Осим тога, у његовим доцније насталим огледима - у позним путописима и песмама такође - приметно је све веће приближавање хришћанским идеалима. У једном од есеја он пише о нежности као „производу хришћанства”, о словенству као истинском хришћанству. У извесном смислу, код Дучића има нечега од умереног стоичара и уздржаног епикурејца, који пре свега верује у древне грчке и хришћанске идеале, у велике идеје и истине.

Зато и не чуди што се свака идеја које ћемо срести у овим књигама може уочити и другде, а многе од њих ће читаоце подсетити на њихова ранија трагања и знатижељне књишке пустоловине. Дучићеве мисли не обележавају никакву нову етапу у мишљењу, нити су производ посебне филозофске теорије која би се могла пронаћи у њиховој основи. Ако је потребно, можда би се ипак могло рећи да у позадини стоји некаква животна филозофија која извире из оптимистичке, разумне вере у позитивне вредности живљења. Религија, етика, естетика, социологија, филозофија, историја, књижевност овде су дати као лична духовна пустоловина. Приступачност, лакоћа и привлачна реторика главне су особине ових есеја оличене у непрестаном и неуморном кретању, као што је још давно истакла Паулина Лебл-Албала:

[...] наш песник ишао је неуморно свима могућим већ означеним путевима, античким и савременим, све су му стазе познате, познате су му све странпутице и лутања и појединаца и читавих народа; познати су му и њихови смели подвизи и кукавиштва, и лепоте душе и нискости тела. Пред нама се, као у каквом филму, развија трака све нових перспектива и слика из повеснице човекове судбине на земљи. Цео свемир је ту. Ништа човеково није му непознато (1938: 277).

Постоје, наравно, читаоци које разноврсност оправдано може да замара, будући да понекад више волимо да се зауставимо на једном месту, да осетимо дух разраде идеја, а не само њихово низање. Бескрајна анегдотичност, шароликост изражена у афоризмима може истовремено читаоца да усмери у више праваца које је немогуће све следити. Дучићев скептицизам победио 
је усредсређеност на једно питање: он напросто жели да око једног питања сучели што је више могуће одговора, да их супротстави, али врло ретко се усуђује да сам донесе властити закључак или барем објасни природу туђих одговора. Отуда је једна од основних примедби поводом Блага цара Радована - а она може да важи и за Jутра са Леутара - била да се ова књига лако чита, али да се, нажалост, исто тако лако заборавља.

Као и у поезији и путопису, у Благу цуара Радована и Јутрима са Леуmapa, бекство у неодређено, аисторично време је друга страна Дучићевог симболистичког, готјеовског отклона од баналног, које сведочи о песничком трагању за оним што је битно и најдубље. Отуда се савременост - коју стратегије есенцијализма смештају у други план - појављује врло ретко или никако. Примера ради, у есеју „О песнику” не само што се не помиње ниједан савремени српски песник већ скоро да се не помињу српски песници уопште, изузев Бранка Радичевића и Војислава Илића. Све је у есејима преломљено кроз привидно универзалне, а заправо - као што би се могло показати - сасвим историјске идеолошке ставове или бинарне опозиције. Пасатизам је веома битна Дучићева стратегија. Он као да полази од прикривене премисе да је модерно друштво сумњиво у политичком и искварено у културном смислу и да су само прошле епохе - стара Грчка и Рим, а донекле и „велике” европске културе у класичном раздобљу 17,18 . и прве половине 19. веку - привлачне и достојне поштовања. Иза таквог далекосежног суда стајала је можда велика истина коју је песник болно наслућивао: наиме, да помно сачињени стихови немају своју одговарајућу улогу у новом буржоаском капиталистичком индустријском систему који их је све више омаловажавао, док је лирска уметност уистину играла некакву улогу у различитим старим режимима ка којима је упирао поглед и за којима је чезнуо. ${ }^{2}$

Можда и у бекству од савремености, Дучић улази у стару литерарну и интелектуалну авантуру у којој су представе о срећи, љубави, пријатељству, херојима, мржњи, карактеру или уљудности неодвојиви део културе европских народа. У том смислу, он се несумњиво показује као заступник ,западне цивилизације”, чија је реалност везана за грчко-римску и јудео-хришћанску традицију, али и за модерну традицију државе-нације као темељног амбијента испољавања културе. Кључни појам европског писања нације, „дух народа”, Дучић - под непосредним утицајем Ренановог предавања „Шта је народ?” - користи у есеју „О родољубљу” из Јутара са Леутара: „Колективни дух једног народа, то је производ заједничке прошлости, историје, заједно подељених срећа и несрећа, победа и пораза. Колективни дух представља истодобно и материјалну и моралну област: заједничке жртве у крви за исте принципе и за исти идеал" (1969: 107). Следећи Ернеста Ренана и заједно са њим преузимајући волунтаристичко одређење нације које потиче из времена Француске револуције, Дучић на једном другом месту износи следеће: „Народ, то не значи заједничка земља, заједничко име, ни заједнички језик, него

\footnotetext{
2 За убедљиву расправу о односу књижевности и тржишта, као и о потискивању поезије од стране нових тржишних механизама на прелому векова видети мој превод Бел-Виљада 2004: $149-188$.
} 
колективни дух, или још боље колективна душа" (1940: 307). А ако је национални идентитет нешто што упућује на дух, а не, према детерминистичком моделу, на крв и тло, онда ништа не може бити природније него да се покуша разумети и описати такав колективни дух који је ствар воље његових припадника, као и заједничке традиције којој они припадају. Отуда се може рећи да је проблем индивидуације културних разлика једна од темељних одлика Дучићеве прозе, а наравно и есеја, која се поставља као питање наративног континуитета, односно продукције и репродукције прича које утемељују нације и њихове културе. Како је време, одмицало Дучић је све више фетишизовао слику о сопственом народу, па тако у Јутрима са Леутара можемо прочитати и да је „српски патриотизам био најпросвећенији и најсвеснији”, или да је династија Немањића била попут фирентинских Медичија „по сјају љубави за културом, и по низу својих владара све бољих и бољих". Како се чини, овакви искази, присутни и у неким његовим песмама, део су песникових личних чежњи и потребе за легитимизацијом властитог порекла и стварања, као и укорењењем у свету једне више, аристократске културе.

Посматран дуго као „западњак” у деведесетим је Дучић постао изнова - као некад код Анице Савић Ребац или Исидоре Секулић - симбол националног (пре свега у култури, а имплицитно и у књижевности), када су пређашње хијерархије почеле да се руше, а идејна криза захтевала нова и другачија утемељења. Његове противречности као да су се сада обратиле широком читалаштву, и они искази из његове прозе коју су неки критичари одбацивала као дилетантску филозофију почели су да задовољавају публику суочену са идеолошким, политичким и националним ломовима. Славко Леовац каже да у прози „Дучић много више констатује и убеђује него што систематски мисли и тумачи" (1985: 95), а Витановић указује на то да је Дучићево писање често производ два паралелна тока, „поетског писања” и „дискурзивног писања" (1997: 125). За модерни свет су ионако пресудни бинаризми као места напетости, почев од самог парадоксалног покушаја да се успостави било какво егзистенцијално јединство (у уметничком делу, на пример) у свету који то не допушта.

Много је боље кретати се рубовима Дучићевих противречности, анализирати их, помирити у једном књижевном интересу, интересу за неодредиво и дијалошко, али са свешћу да он није одређен само пољем књижевности, већ и пољем културе, јер ове противречности не припадају само писцу, већ и култури и језику којем он припада. На крају крајева, главна врлина ових есеја је, као што је још давно истакао Велимир Живојиновић, управо у томе што их је писао Јован Дучић:

$[\ldots]$ што иза тих разговора о вечним људским темама стоји један песник знан и цењен, чији нас унутарњи живот занима зато што нас је дубље заинтересовала његова поезија; што је ова књига размишљања пре свега и више свега аутобиографија једног духа, чији нас унутарњи построј с разлога занима и мами дешифровању (Живојиновић 1929: 490). 
Вредност ових есеја је заправо поезија којима су проткани, њихов особени ритам и израз. Читалац не мора да се сложи са ауторовим ставовима или погледом на свет, његовом „филозофијом”, али ће га завести његова неисцрпна инспирација, па и непредвидљивост кретања кроз текст. У време кад се појавила књига Благо изара Радована, она се посебно ценила, код оних који су је оцењивали позитивно, као једно изразито ерудитно дело, будући да у себе уграђује разнолика знања и велико литерарно искуство - укратко, оно што се тридесетих година могло још увек слободно назвати „животна мудрост". Разуме се да ни мудрост једног Дучића, нити његовог времена, углавном нису примерени времену у којем живимо. Па ипак, његове мисли нас освајају снагом чежње за неким другим, темељнијим и заштићеним светом о којем је ипак много више и он сам сањао него што је у њему живео.

У ствари, Дучић се у белешци која се нашла на почетку Jутара са Леyтара враћа том сну. Песник тамо вели како се са брега Леутара изнад Требиња, могла „на ведром дану видети, преко мора које је у близини, обала Италије. Тај велики видокруг није био без утицаја на мој завичај и његове људе” (1969: 35). Тај „велики видокруг” је у схватања људи уливао дах новог искуства, за које беше довољна сама свест, идеја да негде тамо постоји нешто друго и другачије. Дучићеви огледи, синтеза скоро свега што је прочитао, искусио, свега чиме је био окупиран, истовремено су водич кроз то, нешто, другачије - а што је он сам у огледу „О мирноћи” назвао „Свет, Начело или Правило, Разлог и Морал” (1969: 41). Поред тога што је услов без којег се не може, „велики видокруг” је истовремено и песников позив читаоцу да заузме, у свом времену, прави положај за самостално, слободно и отворено осматрање Блага и̧ара Радована и Јутара са Леутара.

\section{ЛИТЕРАТУРА}

Бел-Виљада 2004: Džin H. Bel-Viljada, Umetnost radi umetnosti i književni život: kako su politika i tržište doprineli uobličavanju ideologije i kulture esteticizma, 1790-1990, Novi Sad: Svetovi.

Витановић 1997: С. Витановић, Јован Дучић у знаки Атене, Београд: Српска акедемија наука и уметности, Балканолошки институт.

Гвозден 2003: В. Гвозден, Јован Дучић путописаи:: оглед из имагологије, Нови Сад: Светови.

Дучић 1996: Ј. Дучић, Благо иара Радована, Београд: Моно.

Дучић 1940: Ј. Дучић, Градови и химере, Београд: Српска књижевна задруга.

Дућић 1969: Ј. Дучић, Јутра са Леутара; Стаза поред пута; Прилози. Сарајево: Свјетлост.

Живојиновић 1929: В. Живојиновић, Филозофски разговори г. Ј. Дучића (Благо изара Радована). Misao, Beograd, XXX, 5-8.

Кашанин 1968: М. Кашанин, Судбине и људи, Београд: Просвета. 
Лебл-Албала 1938: П. Лебл-Албала, Једна књига животне мудрости (Ј. Дучић, Благо циара Радована), Прилози за књижевност, језик, историју и фолклор, Београд, књ. 18, 1/2, 271-278.

Леовац 1985: С. Леовац, Јован Дучић: књижевно дело, Сарајево: Свјетлост.

Мамфорд 2001: Л. Мамфорд, Град у историји, Београд: Book Marso.

Палавестра 1986: П. Палавестра, Историја модерне српске књижевности: златно доба, Београд: СКЗ.

Савић Ребац 1988: А. Савић Ребац, Студије и огледи, Нови Сад: Књижевна заједница.

Секулић 1964: И. Секулић, Сабрана дела, књ. 12, Нови Сад: Матица српска.

Vladimir V. Gvozden

ESSAYIST JOVAN DUČIĆ

(Summary)

The Serbian prose does not have a lot of books like Jovan Dučić's collections of essays Blago cara Radovana (Tsar's Radovan Treasure) and Jutra sa Leutara (Leutar Mornings). Only few writers „dared" to deal in this way with moralistic themes, because they bring a significant intellectual risk to one who approaches them. Through a comparative and contextual analysis, this paper attempts to locate these essays within the broader European tradition. Indeed the essayist Jovan Dučič is an eclectic erudite who, by subjects he dealt with and methods he used, Dučić undoubtedly belongs to the tradition of essayistic writing that had its real beginning with Montaigne in the 16th century and its popular successors such as Ralph Waldo Emerson, author of The Conduct of Life (1860), Maurice Maeterlink, author of Wisdom and Destiny (1898); or Thomas Carlyle with his essays on heroes (1841). In this sense, Dučić as humanistic aesthete is undoubtedly a literary heir of "Western civilization", which is the reality related to the Greco-Roman and Judeo-Christian tradition as well as to the tradition of modern nation-state as a fundamental environment of the emergence of culture. However, this approach also includes a certain restlessness especially visible in Dučić's longing for "eternal" values behind the veil of the same civilization. 